\title{
PREDIKSI JUMLAH PELANGGARAN HUKUM DI LAUT INDONESIA MENGGUNAKAN METODE DOUBLE EXPONENTIAL SMOOTHING
}

\author{
Heru Lumaksono ${ }^{1}$, Hozairi $^{2}$, Buhari $^{3}$, Markus Tukan $^{4}$ \\ ${ }^{1}$ Program Studi Teknik Bangunan Kapal, Politeknik Perkapalan Negeri Surabaya, Surabay, Indonesia \\ ${ }^{2,3}$ Program Studi Teknik Informatika, Universits Islam Madura, Pamekasan, Indonesia \\ ${ }^{4}$ Program Studi Teknik Industri, Universits Pattimura, Ambon, Indonesia \\ heruppns@gmail.com,dr.hozairi@gmail.com
}

\begin{abstract}
ABSTRAK
Pelanggaran hukum dilaut adalah salah satu indikator untuk mengukur tingkat keamanaan suatu bangsa Untuk menjaga stabilitas keamanan dilaut Indonesia maka Pemerintah perlu melakukan prediksi jumlah pelanggaran hukum dilaut untuk menentukan kebijakan berikutnya. Prediksi merupakan kunci keberhasilan Pemerintah untuk mengatur strategi operasi keamanan dilaut Indonesia. Metode yang digunakan untuk prediksi pelanggaran hukum dilaut Indonesia adalah Double Exponential Smoothing, metode Double Exponential Smoothing merupakan metode peramalan yang cukup baik untuk peramalan jangka panjang, jangka menengah maupun jangka pendek. Data yang diolah adalah data pelanggaran hukum dilaut Indonesia sejak 1996 sampai 2019 dari Badan Keamanan Laut Indonesia. Hasil yang diperoleh dari penelitian ini adalah hasil analisa dari tingkat keakuratan dari data MAD, MSE, MAPE, MSE dan RMSE untuk mencari nilai eror terkecil. Hasil penelitian ini memprediksi jumlah pelanggaran hukum dilaut Indonesia pada tahun 2020 akan menurun menjadi 87 kasus dengan nilai konstanta pemulusan data $(\alpha=0,9)$, nilai pemulusan trend $(\gamma=0,2)$, nilai rata-rata kesalahan persentase absolute $(\mathrm{MAPE}=23,85 \%)$ dan nilai akar rata-rata kesalahan (RMSE=67,726). Kontribusi penelitian dapat dijadikan pertimbangan oleh Bakamla untuk mengatur strategi operasi bersama dengan lembaga lain yang memiliki wewenang hukum dilaut Indonesia.
\end{abstract}

\section{Keyword : Prediksi, Pelanggaran, Double Exponential Smoothing}

\section{PENDAHULUAN}

Letak geografis Indonesia yang berada di antara Benua Asia dan Australia serta di antara Samudera Hindia dan Samudera Pasifik telah menempatkan Indonesia pada posisi strategis ditinjau dari segi ekonomi, politik, sosial budaya dan pertahanan keamanan (Keliat, 2009). Selain itu, posisi Indonesia menjadi sangat penting bagi negara-negara dari berbagai kawasan. Namun memberikan dampak yang menguntungkan sekaligus juga mengancam kepentingan Indonesia, sehingga menimbulkan permasalahan yang kompleks baik masalah yang berkaitan dengan bidang keamanan, hukum, ekonomi maupun pertahanan Negara (Kadar, 2015), (I Nengah Putra A, 2016)

Pelanggaran hukum dilaut adalah salah satu indikator untuk mengukur tingkat keamanaan suatu bangsa. Berbagai pelanggaran hukum dilaut mengalami kenaikan secara signifikan dengan berbagai ragam jenis pelanggaran yang mengakibatkan kerugian Negara. Secara global, kenaikan pelanggaran hukum dilaut Indonesia berdampak pada pendapatan Negara, kelangsungan hidup laut dan kedaulatan laut Indonesia (Munaf \& Sulistyaningtyas, 2015), (Setiawan, 2017). Pemerintah dapat melakukan antisipasi untuk pengendalian jumlah pelanggaran hukum dilaut Indonesia dengan melakukan sistem peramalan.

Metode Double Exponential Smoothing (DES) banyak digunakan oleh beberapa peneliti untuk meramalkan beberapa permasalahan seperti meramalkan kurs dollar (Gultom \& Wuryandari, 2015), meramalkan jumlah konsumen produk dan indeks harga konsumen (Etri Pujiati, Desi Yuniarti, 2016), (Sunarmintyastuti et al., 2016), meramalkan hasil tangkapan ikan (Hanafi, Hozairi, 2016), meramalkan produksi tanaman pangan (Rudy Ariyanto, Dwi Puspitasari, 2017), meramalkan jumlah kebutuhan pemakaian air dan jumlah penjualan (Santoso, Widihastuti, \& Kurniadi, 2018), meramalkan jumlah konsumen (Putro, Furqon, \& Wijoyo, 2018), meramalkan kedatangan jumlah wisatawan asing (Hudiyanti, Bachtiar, \& Setiawan, 2019). Berdasarkan pendekatan permasalahan penelitian ini memiliki kebaruan dari obyek penelitian lain karena jenis permasalahan berbeda sehingga mampu memberikan kontribusi kepada Pemerintah khususnya bidang keamanan laut Indonesia.

Peramalan jumlah pelanggaran hukum dilaut Indonesia dapat dilakukan berdasarkan data historis dengan menggunakan metode Double Exponential Smoothing (DES). Metode DES merupakan metode yang digunakan untuk meramalkan data yang tidak teratur dan bervariasi (Tratar, 2016), (Wu, Liu, \& Yang, 2016), (Batselier \& Vanhoucke, 2017). Metode DES merupakan metode yang digunakan untuk meramalkan data yang mengalami trend, apabila data yang digunakan semakin banyak dalam perhitungan maka percentace error peramalannya akan semakin kecil, begitu juga sebaliknya ( $\mathrm{Su}, \mathrm{Gao}$, Guan, \& Su, 2018), (Rendon-sanchez \& Menezes, 2019). Metode DES sangat cocok untuk meramalkan 
jumlah pelanggaran hukum dilaut Indonesia karena mampu meramal jangka panjang dan menengah, terutama tingkat operasional pada Badan Keamanan Laut Indonesia (BAKAMLA).

Bakamla memiliki tugas pokok sebagai komando dan kendali untuk pelaksanaan operasi keamanan, keselamatan dan penegakan hokum diwilayah perairan Indonesia sesuai UU No 32 Tahun 2014 tentang kelautan. Salah satu fungsi Bakamla adalah menyinergikan pelaksanaan patroli yang dilaksanakan oleh dua belas instansi yang memiliki kewenangan di laut (Munaf \& Sulistyaningtyas, 2015), (Hozairi, Buhari, Heru, 2018), (Hozairi, Buhari, Safiudin, Heru Lumaksono, 2019), (Hozairi, Heru Lumaksono, Marcus Tukan, Buhari, 2019). Sinergi antar lembaga menjadi prioritas Bakamla supaya bisa bersama-sama melakukan perencanaan, penganggaran, pelaksanaan dalam proses menjaga keamanan, keselamatan dan penegakan hukum dilaut Indonesia (Hozairi, Heru Lumaksono, Marcus Tukan, 2019).

Penelitian ini bertujuan untuk memprediksi jumlah pelanggaran hukum dilaut Indonesia dengan mengimplementasikan metode Double Exponential Smoothing, hasil dari peramalan tersebut akan dianalisa berdasarkan nilai persentase eror terkecil dari data actual dengan hasil peramalan. Hasil penelitian ini akan memberikan informasi kepada Pemerintah untuk mengatur strategi operasi bersama dalam rangka menurunkan jumlah pelanggaran hukum dilaut Indonesia pada masa mendatang. Selain itu, hasil dari peramalan dapat digunakan untuk mengambil kebijakan mengantisipasi jumlah pelanggaran di laut, selain itu juga manfaat peramalan bisa mengatur pendistribusian armada kapal pengawas dibeberapa wilayah.

\section{TINJAUAN PUSTAKA}

\subsection{Peramalan}

Peramalan adalah suatu seni dan ilmu pengetahuan dalam memprediksi peristiwa pada masa mendatang. Peramalan selalu melibatkan data historis untuk memproyeksikan peristiwa yang akan datang dengan model matematika. Berdasarkan beberapa definisi diatas, pada hakikatnya peramalan merupakan suatu keputusan tentang kemungkinan masa yang akan datang didasarkan fakta-fakta sebelumnya.

Sebelum melakukan peramalan harus diketahui dahulu permasalahan dalam pengambilan keputusan, terdapat dua pendekatan untuk mengatasi persoalan pemodelan keputusan, yaitu: pendekatan kualitatif dan pendekatan kuantitatif. Pendekatan kualitatif tidak digunakan perhitungan-perhitungan dengan rumus dan metode yang pasti melainkan melalui pendapat dari berbagai pihak, seperti opini dewan eksekutif, survey pasar, pendapat seorang pakar, dll. Pendekatan kuantitatif adalah metode peramalan yang mengandalkan data historis dengan menggandalkan ilmu statistik dan matematika sehingga diperoleh hasil yang dapat dipertanggungjawabkan secara ilmiah.

\subsection{Tipe Peramalan}

Tipe peramalan dapat dikelompokkan dalam tiga bagian yaitu:

- Peramalan jangka pendek, Peramalan ini mencakup jangka waktu hingga satu tahun tetapi umumnya kurang dari 3 bulan.

- Peramalan jangka menengah atau intermediate, umumnya mencakup hitungan bulanan hingga 3 tahun.

- Peramalan jangka panjang, Umumnya untuk perencanaan 3 tahun atau lebih.

\subsection{Double Exponential Smoothing Holt}

Peramalan Penghalusan Eksponensial (Exponential Smoothing) merupakan salah satu kategori metode time series yang menggunakan pembobotan data masa lalu untuk melakukan peramalan. Besarnya bobot berubah menurun secara eksponensial bergantung pada data histori.

Penelitian ini menggunakan pendekatan Double Exponential Smoothing Holt. Metode DES Holt pada prinsipnya serupa dengan Brown kecuali pada Holt tidak menggunakan rumus pemulusan berganda secara langsung. Sebagai gantinya, Holt memuluskan nilai trend dengan parameter yang berbeda dari parameter yang digunakan pada deret asli. Ramalan dari pemulusan (dengan nilai antara 0 dan 1).

Rumus Double Exponential Smoothing Holt menggunakan tiga persamaan, dengan rumus sebagai berikut:

$$
\begin{aligned}
& S_{t}=\alpha X_{t}+(1-\alpha)\left(S_{t-1}+b_{t-1}\right) \\
& b_{t}=\gamma\left(S_{t}-S_{t-1}\right)+(1-\gamma) b_{t-1} \\
& F_{t+m}=S_{t}+b_{t} m
\end{aligned}
$$

Dimana:

$\mathrm{S}_{\mathrm{t}}=$ nilai pemulusan eksponensial pada periode ke $\mathrm{t}$

$\mathrm{S}_{\mathrm{t}-1}=$ nilai pemulusan eksponensial pada periode ke $\mathrm{t}-$

$\mathrm{X}_{\mathrm{t}} \quad=$ nilai aktual pada periode ke $\mathrm{t}$

$\mathrm{b}_{\mathrm{t}}=$ nilai trend pada periode ke $\mathrm{t}$

$\mathrm{b}_{\mathrm{t}-1}=$ nilai trend pada periode ke $\mathrm{t}-1$

$\alpha, \gamma=$ parameter pemulusan dengan nilai antara 0 dan

$\mathrm{m}=$ periode yang akan diramalkan

$\mathrm{F}_{\mathrm{t}+\mathrm{m}}=$ ramalan $\mathrm{m}$ periode kedepan

Peramalan diatas menyesuaikan $S_{t}$ secara langsung untuk trend periode sebelumnya, yaitu $b_{t-1}$ dengan menambahkan nilai pemulusan terahir, yaitu $S_{t-1}$. Hal ini membantu untuk menghilangkan kelambatan.

\subsection{Mengukur Kesalahan Peramalan}

Ukuran yang digunakan dalam menghitung keseluruhan dalam kesalahan peramalan. Ukuranukuran ini dapat digunakan untuk membandingkan model peramalan yang berbeda, untuk memonitor peramalan berfungsi dengan baik. Tiga ukuran yang 
paling terkenal adalah Mean Absolute Deviation (MAD), Mean Square Error (MSE) dan Mean Absolute Percent Error (MAPE).

a. ME (Mean Error)

$$
M E=\frac{\sum A_{t}-F_{t}}{n}
$$

b. MAD (Mean Absolute Deviation)

$$
M A D=\frac{\sum\left[A_{t}-F_{t}\right]}{n}
$$

c. MSE (Mean Square Eror)

$$
M S E=\frac{\sum\left[A_{t}-F_{t}\right]^{2}}{n}
$$

d. MAPE (Mean Absolute Percent Eror

$$
M A P E=\frac{\sum_{i}^{n}\left[\frac{A_{t}-F_{t}}{A_{t}}\right] \times 100 \%}{n}
$$

\section{METODOLOGI PENELITIAN}

\subsection{Tahapan Penelitian}

Kegiatan penelitian adalah proses memperoleh suatu pengetahuan atau memecahkan permasalahan yang dihadapi dengan melakukan cara ilmiah, sistematis dan logis. Dalam penelitian bidang apapun, peneliti perlu mengikuti tahapan penelitian dengan tujuan memastikan semua proses ilmiah telah dilakukan secara baik.

Secara garis besar, tahapan-tahapan yang ditempuh dalam melaksanakan penelitian bisa dilihat pada Gambar 1.

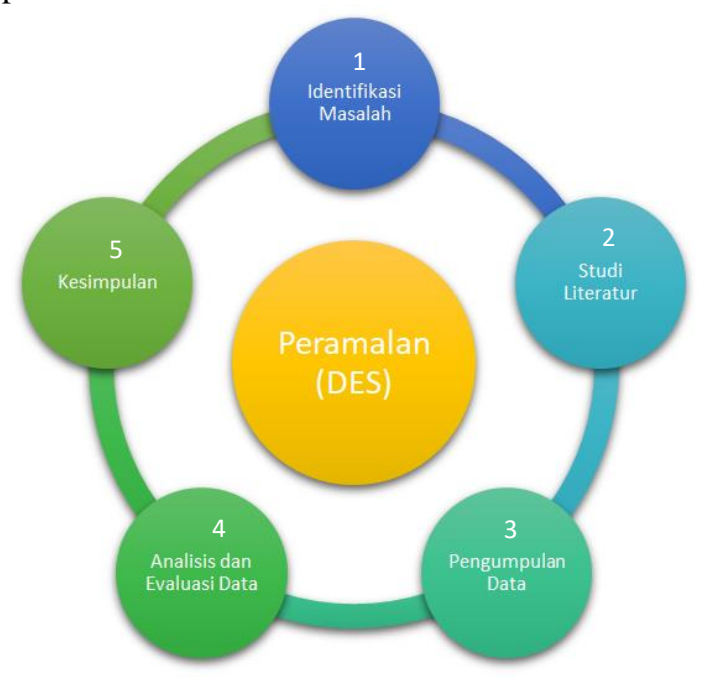

Gambar 1. Tahapan penelitian

Berdasarkan Gambar 1, tahapan penelitian ini disusun menjadi 5 (lima) tahap:

1. Identifikasi masalah bertujuan untuk menentukan permasalahan utama yang dihadapi Pemerintah untuk meminimalisasi pelanggaran hukum dilaut Indonesia.

2. Studi literatur dilakukan dari beberapa paper nasional atau internasional untuk memastikan metode yang paling tepat untuk menyelesaikan permasalahan peramalan pelanggaran hukum dilaut Indonesia.
3. Pengumpulan data dilakukan dengan cara menyebar kuisioner dan wawancara dengan lembaga Pemerintah yang memiliki kewenangan hukum dilaut Indonesia.

4. Analisis dan evaluasi data dilakukan dengan menggunakan metode Double Exponential Smoothing

5. Kesimpulan dilakukan setelah melakukan analisis dan evaluasi.

\subsection{Pengumpulan Data}

Pengumpulan data didapatkan dari lembaga yang memiliki wewenang hukum dilaut Indonesia, yaitu dari TNI AL, KKP, Bakamla, Kemenhub, Polri, Bea Cukai, dsb. Data pelanggaran yang terkumpul sejak tahun 1996 sampai 2019 dengan melakukan evaluasi dan klarifikasi terhadap jenis pelanggaran hukum yang terjadi dilaut Indonesia.

Jumlah data pelanggaran hukum dilaut Indonesia yang terekan sejak tahun 1996 sampai 2019 dapat dilihat pada Tabel 1.

Tabel 1. Jumlah pelanggaran hukum dilaut Indonesia

\begin{tabular}{cc}
\hline $\begin{array}{c}\text { Periode } \\
\text { t }\end{array}$ & $\begin{array}{c}\text { Aktual } \\
\text { At }\end{array}$ \\
\hline 1996 & 228 \\
1997 & 267 \\
1998 & 287 \\
1999 & 421 \\
2000 & 352 \\
2001 & 310 \\
2002 & 229 \\
2003 & 246 \\
2004 & 263 \\
2005 & 160 \\
2006 & 187 \\
2007 & 201 \\
2008 & 295 \\
2009 & 246 \\
2010 & 217 \\
2011 & 160 \\
2012 & 172 \\
2013 & 179 \\
2014 & 123 \\
2015 & 102 \\
2016 & 163 \\
2017 & 132 \\
2018 & 109 \\
2019 & 97 \\
\hline mber: Hasil pengolahan data \\
\end{tabular}


Jenis pelanggaran hukum setelah diklasifikasi berdasarkan data yang dikumpulkan sebagai berikut:

- Pencurian ikan

- Pencurian ikan menggunakan bom

- Menangkap ikan menggunakan bom

- Perampokan

- Pencurian BMKT

- Penyelundupan BBM

- Penyelundupan barang

- Penyelundupan hewan

- Penyelundupan kayu

- Penyelundupan manusia

- Penyelundupan miras

- Penyelundupan narkoba

- Penyelundupan senjata

- Kerusakan ekosistem

- Pembuangan limbah

- Berlayar tanpa izin

- Imigrasi

- Bea cukai

- Pelanggaran batas regional

- Kejahatan ZEE

\subsection{Diagram Alir Double Exponential Smoothing}

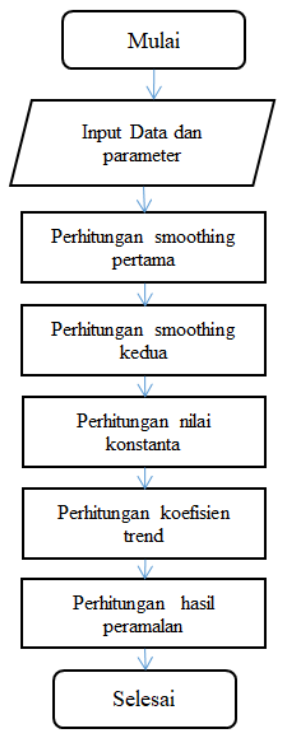

Gambar 2. Diagram alir Double Exponential Smoothing

Berdasarkan Gambar 2 tentang diagram alir Double Exponential Smoothing dimulai dengan memasukkan data histori pelanggaran hukum dilaut Indonesia. Dalam memproses perhitungan dengan metode Double Exponential Smoothing dibutuhkan pula juga masukan berupa nilai parameter $\alpha$. Pemproses pertama dengan mencari nilai Single Exponential Smoothing sebagai nilai pemulusan yang pertama, selanjutnya perhitungan kedua dengan Double Exponential Smoothing selanjutnya dengan memasukkan nilai perhitungan konstanta dan koefisien trend. Jika nilai perhitungan konstanta dan koefisien trend sudah diperoleh maka nilai peramalan akan diketahui.
Selanjutnya setelah hasil peramalan diketahui, maka sistem akan melakukan percobaan dengan menganalisa nilai eror yang terkecil antara hasil peramalan dengan nilai actual, jika diperoleh nilai paling eror maling kecil maka hasil peramalan tersebutlah yang akan dijadikan solusi untuk direkomendasikan.

\section{HASIL DAN PEMBAHASAN}

Berdasarkan data aktual terjadinya pelanggaran hukum dilaut Indonesia sejak tahun 1996 sampai tahun 2019 dapat dilihat pada Gambar 1.

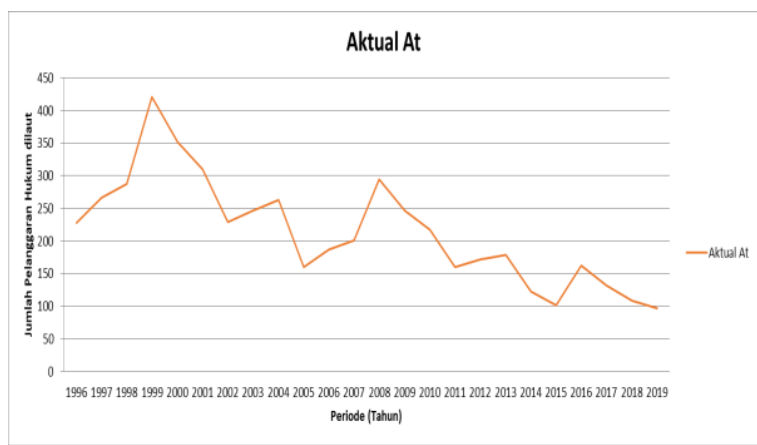

Gambar 3. Grafik aktual pelanggaran hukum dilaut Indonesia

Dari data yang tersedia, maka selanjutnya akan diolah dengan metode Double Exponential Smoothing (DES) Holts dengan tujuan memperoleh prediksi perkiraan jumlah pelanggaran hukum dilaut. Metode DES menggunakan dua konstanta untuk menentukan trend yang lebih baik. Persamaan kedua konstanta antara $\alpha$ dan $\gamma$ yang harus dipilih secara bersamaan dengan variasi parameter antara 0 dan 1 .

Tabel 2. Simulasi perhitungan DES Holt

\begin{tabular}{rrrrrrrrr}
\hline Periode & Actual & Level & Tren & Forcast & Error & Abs Eror & $\begin{array}{r}\text { Percentase } \\
\text { Abs Eror }\end{array}$ & Square Eror \\
\hline 1996 & 228 & 228 & 106 & 334 & & & & \\
1997 & 267 & 274 & 94 & 334 & -67 & 67 & $25 \%$ & 4506 \\
1998 & 287 & 295 & 79 & 367 & -80 & 80 & $28 \%$ & 6457 \\
1999 & 421 & 417 & 88 & 375 & 47 & 47 & $11 \%$ & 2189 \\
2000 & 352 & 367 & 60 & 505 & -153 & 153 & $43 \%$ & 23339 \\
2001 & 310 & 322 & 39 & 427 & -117 & 117 & $38 \%$ & 13696 \\
2002 & 229 & 242 & 15 & 361 & -133 & 133 & $58 \%$ & 17620 \\
2003 & 246 & 247 & 13 & 257 & -11 & 11 & $5 \%$ & 124 \\
2004 & 263 & 263 & 14 & 261 & 2 & 2 & $1 \%$ & 5 \\
2005 & 160 & 171 & -7 & 276 & -117 & 117 & $73 \%$ & 13634 \\
2006 & 187 & 185 & -3 & 164 & 23 & 23 & $12 \%$ & 518 \\
2007 & 201 & 199 & 0 & 181 & 20 & 20 & $10 \%$ & 384 \\
2008 & 295 & 285 & 18 & 199 & 96 & 96 & $32 \%$ & 9130 \\
2009 & 246 & 252 & 7 & 303 & -57 & 57 & $23 \%$ & 3220 \\
2010 & 217 & 221 & 0 & 259 & -42 & 42 & $19 \%$ & 1766 \\
2011 & 160 & 166 & -11 & 221 & -61 & 61 & $38 \%$ & 3749 \\
2012 & 172 & 171 & -8 & 155 & 17 & 17 & $10 \%$ & 302 \\
2013 & 179 & 178 & -5 & 162 & 17 & 17 & $9 \%$ & 280 \\
2014 & 123 & 128 & -14 & 172 & -49 & 49 & $40 \%$ & 2445 \\
2015 & 102 & 103 & -16 & 114 & -12 & 12 & $12 \%$ & 143 \\
2016 & 163 & 155 & -2 & 87 & 76 & 76 & $47 \%$ & 5766 \\
2017 & 132 & 134 & -6 & 153 & -21 & 21 & $16 \%$ & 439 \\
2018 & 109 & 111 & -10 & 128 & -19 & 19 & $17 \%$ & 356 \\
2019 & 97 & 97 & -10 & 101 & -4 & 4 & $4 \%$ & 18 \\
2020 & & & & 87 & -647 & 1240 & $572 \%$ & 110084 \\
\hline
\end{tabular}

Sumber: Hasil penelitian 
Berdasarkan rumus persamaan (1), (2) dan (3) maka selanjutnya akan dilakukan analisa peramalan, untuk mendapatkan nilai $\alpha$ dan $\gamma$ yang optimal, penelitian ini mengacu kapada hasil percobaan nilai $\alpha$ dan $\gamma$ yang terbaik berdasarkan penelitian (Nila Yuwida, Lukman Hanafi, 2012) dengan melakukan percobaan konstanta pemulusan untuk data $(0 \leq \alpha \leq 1)$ dan konstanta pemulusan untuk estimasi trend $(0 \leq \gamma \leq 1)$.

Tabel 2. Nilai MAPE \& RMSE terkecil dari plot nilai $\alpha$ dan $\gamma$

\begin{tabular}{ccccccc}
\hline $\boldsymbol{\alpha}$ & $\boldsymbol{\gamma}$ & ME & MAD & MAPE & MSE & RMSE \\
\hline 0,1 & 0,9 & $-38,670$ & 152,839 & $73,38 \%$ & 33567,01 & 183,213 \\
0,2 & 0,9 & $-29,717$ & 89,072 & $41,39 \%$ & 13297,93 & 115,317 \\
0,3 & 0,9 & $-16,068$ & 69,055 & $32,20 \%$ & 7676,34 & 87,615 \\
0,4 & 0,6 & $-19,570$ & 60,620 & $27,53 \%$ & 6335,60 & 79,596 \\
0,5 & 0,4 & $-24,074$ & 56,484 & $25,58 \%$ & 5795,26 & 76,127 \\
0,6 & 0,2 & $-40,350$ & 57,868 & $26,37 \%$ & 6548,47 & 80,923 \\
0,7 & 0,2 & $-34,595$ & 53,883 & $24,57 \%$ & 5531,66 & 74,375 \\
0,8 & 0,2 & $-30,294$ & 52,492 & $24,13 \%$ & 4931,60 & 70,225 \\
0,9 & 0,2 & $-26,938$ & 51,677 & $23,85 \%$ & 4586,83 & 67,726 \\
\hline
\end{tabular}

Sumber: Hasil penelitian

Berdasarkan analisa percobaan penentuan plot nilai $\alpha$ dan $\gamma$ diperoleh hasil seperti terlihat pada Tabel 2, dari data nilai konstanta pemulusan data dan trend diperoleh nilai eror terkecil adalah $\alpha=0,9$ dan $\gamma=0,2$ dengan nilai MAPE $=23,85 \%$ dan nilai $\mathrm{RMSE}$ $=67,726$.

ME merupakan rata-rata eror yang diperoleh dari penjumlahan masing-masing nilai eror, lalu dibagi dengan jumlah data yang ada diperoleh nilai. MAD adalah nilai rata-rata absolut eror yang diperoleh dari data masing-masing nilai absolut eror lalu dibagi jumlah data. MAPE adalah rata-rata persentase nilai eror yang didapat dari jumlah masing-masing nilai persen eror, lalu dibagi dengan jumlah data. MSE adalah nilai rata-rata kuadrat eror yang didapat dari hasil penjumlahan nilai square eror, lalu dibagi dengan jumlah data. RMSE adalah nilai akar dari nilai MSE. Untuk penelitian ini akan disajikan nilai ME, MAD, MAPE, MSE dan RMSE sebagai bahan analisa untuk penentuan nilai prediksi yang terbaik.

Hasil peramalan dengan konstanta pemulusan data dan tren $(\alpha=0,9$ dan $\gamma=0,2)$ dapat dilihat pada Gambar 4. Hasil peramalan untuk 6 (enam) tahun terahir diperoleh hasil [ $\left.87 \begin{array}{lllll}87 & 66 & 56 & 45 & 35\end{array}\right]$, secara trend hasil prediksi menunjukkan penurunan pada enam tahun terahir, hal ini bisa dipengaruhi oleh beberapa program Pemerintah yang fokus kepada pengamanan laut Indonesia dengan mengoptimalkan seluruh lembaga Pemerintah yang memiliki kewenangan hukum dilaut, hal tersebut juga dipengaruhi oleh kerjasama antara beberapa Negara tetangga yang akan saling menjaga kedaulatan wilayah masing-masing sesuai komitmen kerjasama luar negeri.

Garis merah pada Gambar 4 menjelaskan data aktual kejadian pelanggaran hukum dilaut Indonesia, garis biru adalah grafik hasil peramalan dengan pemulusan dua kali. Nilai persentase eror peramalan $\alpha=0,9$ dan $\gamma=0,2$ diperoleh nilai rata-rata persentase eror MAPE $=23,85 \%$ dan RMSE $=67,726$. Tren hasil peramalan pada tahun 2020 sampai 2025 cenderung menurun, hal ini menunjukkan pengamanan laut Indonesia semakin baik sehingga terjadinya pelanggaran hukum dilaut lajunya menurun, tetapi hasil prediksi ini belum mempertimbangkan faktor-faktor eksternal dan internal yang selalu dinamis setiap tahun tergantung kondisi ekonomi dan politik dunia.

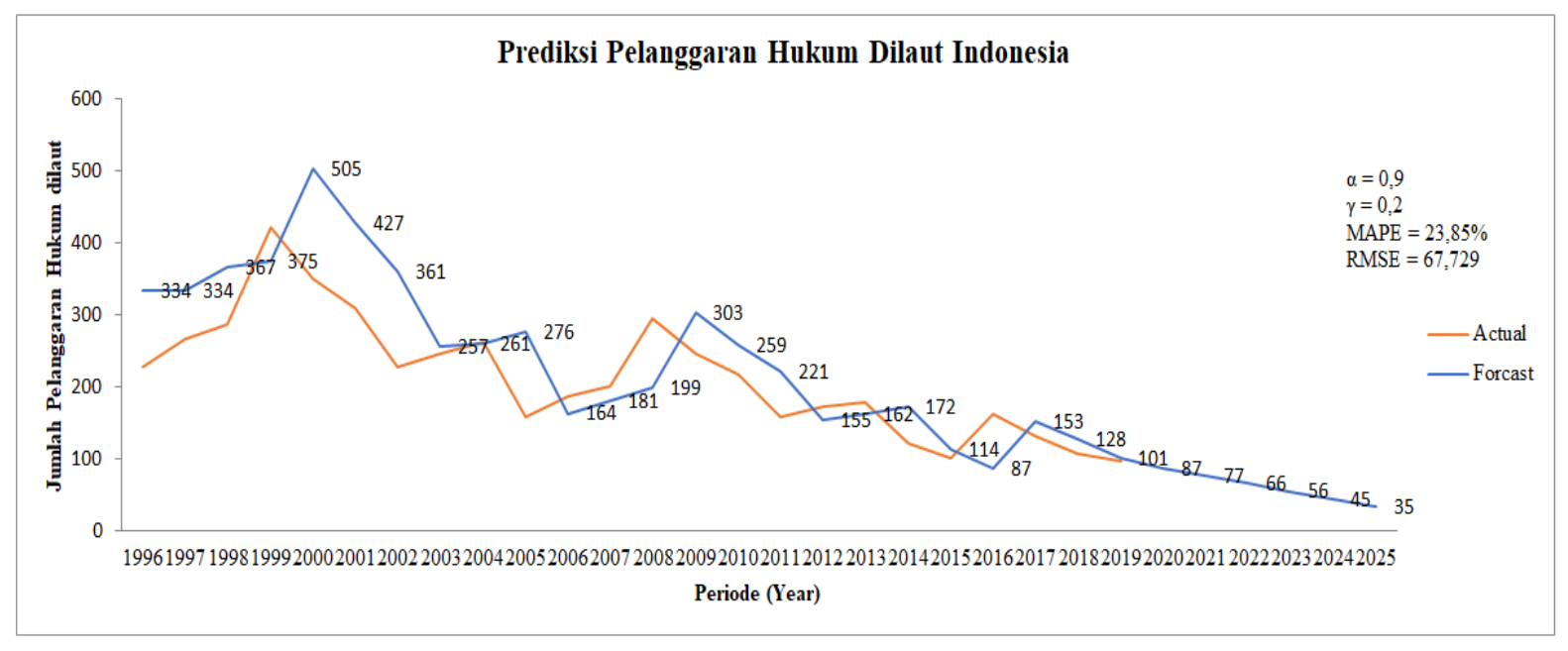

Gambar 4. Hasil prediksi pelanggaran hukum dilaut Indonesia dengan nilai konstanta $\alpha=0,9$ dan $\gamma=0,2$ 
Hasil penelitian ini bisa dikembangkan dengan meperhatikan faktor internal dan faktor eksternal yang mempengaruhi kondisi keamanan laut Indonesia. Secara umum penelitian ini bisa dijadikan acuan oleh Pemerintah untuk mengatur strategi dan model operasi keamanan laut secara bersama-sama yang dipimpin oleh Badan Keamanan Laut Indonesia. Hasil penelitian ini bisa dijadikan acuan supaya Pemerintah tetap waspada terhadap potensi pelanggaran dilaut Indonesia supaya Indonesia yang tiga perempat laut bisa tetap aman dan mampu meningkatkan devisa Negara.

\section{KESIMPULAN}

Berdasarkan hasil penelitian yang telah dilakukan dapat diambil kesimpulan sebagai berikut:

- Hasil perhitungan dengan metode Double Exponential Smoothing dapat digunakan untuk prediksi jumlah pelanggaran hukum dilaut Indonesia.

- Nilai yang paling optimal untuk konstanta pemulusan data $(\alpha=0,9)$ dan nilai pemulusan trend $(\gamma=0,2)$ sehingga diperoleh nilai rata-rata kesalahan persentase absolute $(\mathrm{MAPE}=23,85 \%)$ dan nilai akar rata-rata kesalahan $(\mathrm{RMSE}=67,726)$.

- Hasil penelitian ini memprediksi jumlah pelanggaran hukum dilaut Indonesia pada tahun 2020 sampai 2025 cenderung menurun dengan hasil jumlah prediksi sebagai berikut [87 7766564535 ].

- Penelitian ini belum mempertimbangkan faktor internal dan faktor eksternal, sehingga hasil prediksi sewaktu-waktu akan bisa berubah sesuai kondisi ekonomi Indonesia dan politik dunia.

\section{UCAPAN TERIMA KASIH:}

Penelitian ini merupakan bagian dari Penelitian Strategis Nasional Konsorsium (PSNK) yang didanai pada Tahun 2020, oleh karena itu penulis ingin mengucapkan terima kasih kepada Kementrian Riset, Teknologi dan Perguruan Tinggi Republik Indonesia (Kemenristek Dikti). Tidak lupa kami juga ingin mengucapkan banyak terima kasih kepada Badan keamanan Laut Republik Indonesia (Bakamla RI) yang telah mendukung dan membantu penelitian ini.

\section{DAFTAR PUSTAKA}

[1] Batselier, J., \& Vanhoucke, M. (2017). ScienceDirect Improving project forecast accuracy by integrating earned value management with exponential smoothing and reference class forecasting. JPMA, 35(1), 28 43.

https://doi.org/10.1016/j.ijproman.2016.10.003

[2] Etri Pujiati, Desi Yuniarti, R. G. (2016). Peramalan Dengan Menggunakan Metode Double Exponential Smoothing Dari Brown (
Studi Kasus : Indeks Harga Konsumen ( IHK ) Kota Samarinda ) Forecasting Using Double Exponential Smoothing Method Of Brown ( Case Study: The Consumer Price Index ( CPI ) City. Jurnal Eksponensial, 7(1), 33-40.

[3] Gultom, N. Y., \& Wuryandari, T. (2015). PREDIKSI NILAI KURS DOLLAR AMERIKA MENGGUNAKAN EXPONENTIAL SMOOTHING DENGAN KAJIAN GRAFIK MOVING AVERAGE (MA) DAN EXPONENTIALLY WEIGHTED MOVING AVERAGE (EWMA) (Studi Kasus: Kurs Jual dan Kurs Beli Dollar Amerika). Jurnal Gaussian, 4(4), 957-966.

[4] Hanafi, Hozairi, F. A. (2016). Imlementasi Metode Double Exponential Smoothing Untuk Meramal Kebutuhan Ikan Teri di UD. Bulan Purnama Sotabar Pasean Pamekasan. 2016(Sehati), 16-17.

[5] Hozairi, Buhari, Heru, M. (2018). Determining The Influencing Factors of The Indonesian Maritime Security Using Analytical Hierarcy Process. Jurnal Pertahanan, 4(1), 61-75. Retrieved from http://jurnal.idu.ac.id/index.php/DefenseJourna 1/article/view/253/pdf4

[6] Hozairi, Buhari, Safiudin, Heru Lumaksono, M. T. (2019). Perancangan Enterprise Resource Planning Badan Keamanan Kelautan Indonesia Untuk Membangun Sinergi Kelembagaan Negara. 4(2).

[7] Hozairi, Heru Lumaksono, Marcus Tukan, Buhari, B. A. U. (2019). Optimization of Determination of the Number of Fisheries Supervisory Vessels in the Fisheries Management Area -713 Using Genetic Algorithms. International Conference on Computer Science, Information Technology and Electrical Engineering (ICOMITEE), 1-6.

[8] Hozairi, Heru Lumaksono, Marcus Tukan, B. (2019). Assessment of The Most Influential Factors on Indonesian Maritime Security Using Fuzzy Analytical Hierarchy Process. International Seminar on Research of Information Technology and Intelligent Systems (ISRITI), 1-6.

[9] Hudiyanti, C. V., Bachtiar, F. A., \& Setiawan, B. D. (2019). Perbandingan Double Moving Average dan Double Exponential Smoothing untuk Peramalan Jumlah Kedatangan Wisatawan Mancanegara di Bandara Ngurah Rai. Jurnal Pengembangan Teknologi Informasi Dan Ilmu Komputer, 3(3), 26672672.

[10] I Nengah Putra A, A. H. (2016). Analisa Peluang dan Ancaman Keamanan Maritim Indonesia Sebagai Dampak Perkembangan Lingkungan Strategis. V1-V22.

[11] Kadar, A. (2015). Pengelolaan Kemaritiman Menuju Indonesia sebagai Poros Maritim 
Dunia. Jurnal Keamanan Nasional, VI(21), 427-442.

[12] Keliat, M. (2009). Keamanan Maritim dan Implikasi Kebijakanya bagi Indonesia. Jurnal Ilmu Sosial Dan Ilmu Politik, 13, 111-129.

[13] Munaf, D. R., \& Sulistyaningtyas, T. (2015). Sistem Operasi Tersinergi Bakamla Sesuai Dengan Undang-Undang Nomor 32 Tahun 2014 Tentang Kelautan. Jurnal Sosioteknologi, 14(3), 273-287.

[14] Nila Yuwida, Lukman Hanafi, N. W. (2012). Estimasi Parameter Alpha dan Theta Dalam Pemulusan Ekponensial Ganda Dua Parameter Dengan Metode Modifikasi Golden Section. Jurnal Sains Dan Seni ITS, 1(1).

[15] Putro, B., Furqon, M. T., \& Wijoyo, S. H. (2018). Prediksi Jumlah Kebutuhan Pemakaian Air Menggunakan Metode Exponential Smoothing ( Studi Kasus : PDAM Kota Malang ). Jurnal Pengembangan Teknologi Informasi Dan Ilmu Komputer, 2(11), 4679-4686.

[16] Rendon-sanchez, J. F., \& Menezes, L. M. De. (2019). Structural combination of seasonal exponential smoothing forecasts applied to load forecasting. European Journal of Operational Research, 275(3), 916-924. https://doi.org/10.1016/j.ejor.2018.12.013

[17] Rudy Ariyanto, Dwi Puspitasari, F. E. (2017). PENERAPAN METODE DOUBLE EXPONENTIAL SMOOTHING PADA. Jurnal Informatika Polinema, 4(1), 57-62.
[18] Santoso, D. S., Widihastuti, I., \& Kurniadi, D. (2018). Prediksi Jumlah Penjualan pada Toko Karya Bandung Menggunakan Double Exponential Smoothing. Jurnal Transistor Elektro Dan Informatika, 3(2), 87-89.

[19] Setiawan, A. (2017). Keamanan Maritim di Laut Cina Selatan: Tinjauan atas Analisa Barry Buzan. Jurnal Keamanan Nasional, 3(1), 3362.

[20] Su, Y., Gao, W., Guan, D., \& Su, W. (2018). Dynamic assessment and forecast of urban water ecological footprint based on exponential smoothing analysis. Journal of Cleaner Production, 195, 354-364. https://doi.org/10.1016/j.jclepro.2018.05.184

[21] Sunarmintyastuti, L., Alfarisi, S., Hasanusi, F. S., Studi, P., Informatika, T., Teknik, F., ... Gamis, B. (2016). Aplikasi peramalan penentuan jumlah permintaan konsumen terhadap produk bordir pada kota tasikmalaya 1,2,3. Konferensi Nasional Teknologi Informasi Dan Komunikasi (KNASTIK), (November), 5362.

[22] Tratar, L. F. (2016). Int . J . Production Economics Demand forecasting with fourparameter exponential smoothing. 181, 162173. https://doi.org/10.1016/j.ijpe.2016.08.004

[23] Wu, L., Liu, S., \& Yang, Y. (2016). Grey double exponential smoothing model and its application on pig price forecasting in China. Applied Soft Computing Journal, 39, 117-123. https://doi.org/10.1016/j.asoc.2015.09.054 